\title{
Demineralization effect of EDTA, EGTA, CDTA and citric acid on root dentin: a comparative study
}

\section{Efeito do EDTA, EGTA, CDTA e ácido cítrico na desmineralização da dentina radicular: estudo comparativo}

\author{
Simone Maria Galvão de Sousa* \\ Thelma Lopes Silva**
}

\begin{abstract}
The purpose of this study was to biochemically compare the decalcifying effects of 1\% EDTA (pH 7.4), 1\% EGTA (pH 7.4), 1\% CDTA ( $\mathrm{pH} 7.4$ ), 1\% citric acid solutions ( $\mathrm{pH} 1.0$ and 7.4) and saline solution (control) on root dentin. Forty-eight single-rooted teeth were used in this study. The canals were instrumented by the step-back technique and the roots were randomly divided into six equal experimental groups $(\mathrm{n}=8)$ according to the irrigating agent tested. A total of $30 \mu \mathrm{L}$ of each solution was pipetted into the root canal and allowed to set undisturbed for 5 minutes. After this time, $15 \mu \mathrm{L}$ of the solutions were removed from each canal using a Hamilton syringe and placed in a container with $5 \mathrm{~mL}$ of deionised water. The $\mu \mathrm{g} / \mathrm{mL}$ concentration of calcium ion $\left(\mathrm{Ca}^{2+}\right)$ extracted from the root canal samples was determined using inductively coupled plasma-atomic emission spectrometry (ICPAES). Data were analysed by means of the Kruskal-Wallis and Mood's median tests. Citric acid solution at $\mathrm{pH} 1.0$ removed more calcium than at $\mathrm{pH} 7.4$ and than the other chelating solutions tested $(\mathrm{p}<0.05)$. No differences were observed between EDTA and EGTA. Both EDTA and EGTA removed significantly more calcium than CDTA and citric acid at $\mathrm{pH} 7.4(\mathrm{p}<0.05)$. There were no differences between citric acid at $\mathrm{pH} 7.4$ and saline solution, which had the least efficacy for $\mathrm{Ca}^{2+}$ extraction $(\mathrm{p}>0.05)$. These results indicate that citric acid at $\mathrm{pH} 1.0$ is a good alternative as an irrigating solution to remove the smear layer and facilitate the biomechanical procedures.
\end{abstract}

DESCRIPTORS: Chelating agent; Citric acid; Edetic acid; Egtazic acid.

\begin{abstract}
RESUMO: Este trabalho teve como objetivo comparar o efeito desmineralizante do EDTA (pH 7,4), EGTA (pH 7,4), CDTA (pH 7,4), ácido cítrico (pH 1,0 e 7,4) e da solução salina (controle) sobre a dentina radicular. Todas as soluções teste foram preparadas na concentração de 1\%. Quarenta e oito dentes unirradiculares recém-extraídos foram utilizados neste experimento. Após a instrumentação dos canais radiculares pela técnica "step-back", as raízes foram aleatoriamente divididas em 6 grupos experimentais $(n=8)$ de acordo com a solução teste utilizada na irrigação final. Em cada grupo, $30 \mu \mathrm{L}$ da solução teste foram pipetados no interior de cada canal radicular e mantidos estáveis por 5 minutos. Decorrido esse período, $15 \mu \mathrm{L}$ da solução foram removidos do canal e depositados em frasco contendo $5 \mathrm{~mL}$ de água deionizada. A concentração de $\mathrm{Ca}^{2+}(\mu \mathrm{g} / \mathrm{mL})$ extraída dos espécimes foi determinada pela espectrometria de absorção de massa (ICP-AES); e os dados foram submetidos à análise estatística pelos testes de Kruskal-Wallis e de mediana de Mood. O ácido cítrico em pH 1,0 foi a solução mais efetiva na remoção de Ca ${ }^{2+}$ comparativamente às demais soluções-teste $(\mathrm{p}<0,05)$. Nenhuma diferença estatística foi observada entre a ação do EDTA e a do EGTA. Ambos os quelantes removeram significantemente mais $\mathrm{Ca}^{2+}$ que o CDTA e o ácido cítrico em pH 7,4 (p < 0,05). Não houve diferença significante entre ácido cítrico em pH 7,4 e solução salina $(\mathrm{p}>0,05)$. Os resultados deste estudo indicam que o ácido cítrico em solução de pH 1,0 apresenta-se como uma boa opção para remover a "smear layer" e facilitar o preparo biomecânico do sistema de canal radicular.
\end{abstract}

DESCRITORES: Quelantes; Ácido cítrico; Ácido edético; Ácido egtázico.

\section{INTRODUCTION}

Mechanically prepared dentin surfaces are always covered with the so-called smear layer, a loosely bonded amorphous layer of organic and inorganic debris. Thus, several chelating agents and acids have been used to remove this layer, with varying degrees of success.
These irrigating solutions have been chosen due to their direct action over calcium ions. The calcium present in hydroxyapatite crystals is one of the main inorganic elements of dentin. Any change in the calcium ratio can significantly alter the original proportion of organic and inorganic

\footnotetext{
* Associate Researcher, PhD, Department of Metallurgy and Material Science, Pontifical Catholic University of Rio de Janeiro.

** Biochemist, MS, Department of Biochemistry, School of Dentistry of Bauru, University of São Paulo.
} 
Sousa SMG, Silva TL. Demineralization effect of EDTA, EGTA, CDTA and citric acid on root dentin: a comparative study. Braz Oral Res 2005;19(3):188-92.

components, which can alter dentin permeability, microhardness and solubility.

Although EDTA has a long-standing history as the agent of choice in Endodontics, researchers have reported its irritating potential ${ }^{7,9-11}$. Recently, EGTA has also been recommended for root canal biomechanical preparation, since it presents a more precise action on calcium ions than EDTA $^{1,2,9,12,16}$. Another chelating agent, CDTA, has also been reported to significantly bind the divalent cation. EGTA and CDTA have been used in medicine to obtain calcium-free environments. Recent studies have investigated the application of both chelating agents as an alternative solution to remove the smear layer. Calt, Serper $^{1}$ (2000) and Viswanath et al. ${ }^{16}$ (2003) compared the effect of EDTA and EGTA on removal of the smear layer by using scanning electron microscopy. Cruz-Filho et $a .^{2}$ (2001) and Sousa-Neto et al. ${ }^{12}$ (2002) evaluated the influence of $15 \%$ EDTA, $1 \%$ CDTA and $1 \%$ EGTA on root dentin microhardness, and dentin adhesiveness and microleakage, respectively. In the study of Cruz-Filho et al. ${ }^{2}$ (2001), EDTA was associated with a surfactant (Cetavlon). It is important to note that, in these investigations, the EDTA concentration tested was between 15-17\%, and $1 \%$ was the concentration of EGTA and CDTA solutions. No study has yet compared all chelating agents using the same concentration.

Citric acid has also been studied for its ability as a decalcifying and cleansing solution in root canal irrigation ${ }^{8,13,14,17}$. However, in some scanning electron microscope studies, it was observed that citric acid left precipitated crystals in the root canal walls ${ }^{3,4}$. It is a biological and organic acid, with sufficient tissue compatibility $6,7,10,11,15$.

Studies have demonstrated that the $\mathrm{pH}$ and concentration of demineralising solutions are important factors to be considered in their action in removing surface smear layer ${ }^{4,5}$. A literature review has revealed that different mixtures, concentrations, $\mathrm{pH}$, working time and methods have been used to evaluate the irrigating solutions.

Thus, considering these factors, this study was conducted to compare in vitro the decalcifying effect of 1\% citric acid, 1\% EDTA, 1\% EGTA, 1\% CDTA and saline solution (control) on root dentin, by using inductively coupled plasma-atomic emission spectrometry (ICP-AES). The $\mathrm{pH}$ of the test solutions was 7.4 for all chelating agents and 1.0 and 7.4 for citric acid. The reason to evaluate two different $\mathrm{pH}$ values for the citric acid group was based on the long-standing studies about its best action at lower $\mathrm{pH}^{4,5}$, and inclusion of a second value ( $\mathrm{pH} 7.4)$ was intended to obtain a more accurate comparative result.

\section{MATERIAL AND METHODS Test materials}

The materials used were: 1\% EDTA pH 7.4 (ethylene-diaminetetra-acetic acid; Merck, Darmstadt, Germany); 1\% EGTA pH 7.4 (ethylene-glycol-etherdiaminetetra-acetic acid; Sigma, St. Louis, MO, USA); CDTA (1,2 cyclohexane-diaminetetra-acetic acid, Sigma, St. Louis, MO, USA); $1 \%$ citric acid pH 1.0 and 7.4 (Merck, Darmstadt, Germany) and saline solution (control; Merck, Darmstadt, Germany). All test solutions were freshly prepared. The salts were weighed and diluted in deionised water (Permution E.J. Krieger \& Cia. Ltda., Curitiba, Brazil), and their $\mathrm{pH}$ was adjusted (pH meter B371, Micronal, São Paulo, Brazilian Manufacturing) by addition of hydrochloric acid $(\mathrm{HCl}$ - Merck S.A. Indústria Quimica, Rio de Janeiro, Brazil). The molar concentrations of the acid solutions were: $\mathrm{EDTA}=0.0263 \mathrm{~mol} / \mathrm{L}$, $\mathrm{EGTA}=0.0213 \mathrm{~mol} / \mathrm{L}, \mathrm{CDTA}=0.0274 \mathrm{~mol} / \mathrm{L}$, and citric acid $=0.0520 \mathrm{~mol} / \mathrm{L}$.

\section{Procedure}

Forty-eight single-rooted freshly extracted human teeth with straight root canals and similar length were used in this study. The anatomical crowns were removed transversally at the cementoenamel junction, and the pulp tissue was extirpated. The working length of all teeth was established by passing a \#15 K-file through the apical foramen and then reducing the length by $1.0 \mathrm{~mm}$. The canals were instrumented by the step-back technique to \#70 K-file (Dentsply Maillefer, Ballaigues, Switzerland) with the minimum master apical file \#45. During instrumentation, each canal was copiously irrigated with $20 \mathrm{~mL}$ of $1 \% \mathrm{NaOCl}$ (Biodinâmica, Ibiporã, PR, Brazil). Then, the roots were randomly divided into six equal experimental groups $(n=8)$ according to the irrigator tested. For all groups, $30 \mu \mathrm{L}$ of each solution were pipetted into the root canal and allowed to set undisturbed for 5 minutes. After this time, $15 \mu \mathrm{L}$ of the solutions were removed from the root canals using a Hamilton syringe (Hamilton Company, Reno, Nevada, USA) and placed in a container with $5 \mathrm{~mL}$ of deionised water. The concentration of $\mathrm{Ca}^{2+}(\mu \mathrm{g} /$ $\mathrm{mL}$ ) was determined using inductively coupled 
Sousa SMG, Silva TL. Demineralization effect of EDTA, EGTA, CDTA and citric acid on root dentin: a comparative study. Braz Oral

Res 2005;19(3):188-92.

plasma-atomic emission spectrometry (ICP-AES, Spectrometer plasma 400, Pelkin Elmer, Shelton, CT, USA). The data were statistically analysed by using the nonparametric Kruskal-Wallis test and Mood's median test for multiple comparisons, at the significance level of $5 \%(\mathrm{p}<0.05)$.

\section{RESULTS}

The means, standard deviations (SD), medians (semi-interquartile range) and minimum and maximum values of $\mathrm{Ca}^{2+}$ concentrations $(\mu \mathrm{g} / \mathrm{mL})$ in all experimental groups are shown in Table 1.

The Kruskal-Wallis test shows that there were statistical differences between the acids in terms of $\mathrm{Ca}^{2+}$ concentration. Mood's median test (Table 2) showed statistically significant difference between citric acid solution at $\mathrm{pH} 1.0$ and the other groups $(\mathrm{p}<0.05)$. This solution removed more calcium than citric acid solution at $\mathrm{pH} 7.4$ and the other chelating solutions tested. Moreover, no differences were noted between EDTA and EGTA. Both chelating agents removed significantly more calcium than CDTA and citric acid at pH 7.4 ( $\mathrm{p}<0.05)$. There were no differences between citric acid at
pH 7.4 and saline solution, which had the least efficacy for $\mathrm{Ca}^{2+}$ extraction $(\mathrm{p}<0.05)$.

\section{DISCUSSION}

In this in vitro study, it was noteworthy that citric acid solution is not effective for $\mathrm{Ca}^{2+}$ removal at neutral pH. While EDTA, EGTA and CDTA act as chelating agents at neutral $\mathrm{pH}$, citric acid acts better at lower $\mathrm{pH}$ values.

The statistical data showed that $1 \%$ citric acid at $\mathrm{pH} 1.0$ was the best solution to remove calcium from the root dentin. Furthermore, considering the concentration factor, even though the $1 \%$ citric acid solution ( $\mathrm{pH}$ 1.0) was employed, i.e., at a lower concentration, better results were obtained when compared to the EDTA, EGTA, and CDTA solution groups. The present results are in agreement with those of Hennequin et al. ${ }^{5}$ (1994) and Haznedaroglu ${ }^{4}$ (2003).

According to both previous studies, the $\mathrm{pH}$ of citric acid solution has been shown to be a more important factor to demineralisation than concentration. Sterrett et al. ${ }^{14}$ (1991) reported that this phenomenon may be due to a balance between the decrease in $\mathrm{pH}$ and the increase in viscosity of the

TABLE 1 - Means, standard deviations (SD), medians (semi-interquartile range) and minimum and maximum values of $\mathrm{Ca}^{2+}$ concentrations $(\mu \mathrm{g} / \mathrm{mL})$ in all experimental groups.

\begin{tabular}{l|r|r|r|r}
\hline \multicolumn{1}{c|}{ Groups } & Means $\pm \mathrm{SD}$ & $\begin{array}{c}\text { Median } \\
\text { (semi-interquartile range) }\end{array}$ & Minimum value & Maximum value \\
\hline EDTA & $2.68 \pm 0.24$ & $2.63 \pm 0.24$ & 2.45 & 2.98 \\
\hline EGTA & $2.54 \pm 0.37$ & $2.68 \pm 0.35$ & 1.97 & 2.96 \\
\hline CDTA & $1.46 \pm 0.13$ & $1.45 \pm 0.09$ & 1.24 & 1.66 \\
\hline Citric acid pH 1.0 & $11.86 \pm 1.23$ & $11.93 \pm 1.10$ & 0.16 & 0.31 \\
\hline Citric acid pH 7.4 & $0.20 \pm 0.04$ & $0.18 \pm 0.02$ & 0.32 & 1.71 \\
\hline Saline & $0.85 \pm 0.49$ & $0.82 \pm 0.44$ & \\
\hline \hline
\end{tabular}

TABLE 2 - Mood's median test for multiple comparisons.

\begin{tabular}{l|c|c|c|c|c|c}
\hline \hline & EDTA & EGTA & CDTA & Citric acid (pH 1.0) & Citric acid (pH 7.4) & Saline solution \\
\hline EDTA & - & & & & & \\
\hline EGTA & $(\mathrm{n}-\mathrm{s})$ & - & & & & \\
\hline CDTA & $*$ & $*$ & - & & & \\
\hline Citric acid (pH 1.0) & $*$ & $*$ & $*$ & $*$ & - & \\
\hline Citric acid (pH 7.4) & $*$ & $*$ & $*$ & $*$ & $(\mathrm{n}-\mathrm{s})$ & - \\
\hline Saline solution & $*$ & $*$ & $*$ & $*$ & & \\
\hline \hline
\end{tabular}

Chi square $($ critical value) $=48.00 ;$ degrees of freedom $=5 ; p=0.000 ;$ *significant at $p<0.05$.

Test value $($ calculated $\mathrm{H})=43.85$; degrees of freedom $=5 ; \mathrm{p}=0.000 ;(\mathrm{n}-\mathrm{s})=$ not significant at $\mathrm{p}>0.05$. 
Sousa SMG, Silva TL. Demineralization effect of EDTA, EGTA, CDTA and citric acid on root dentin: a comparative study. Braz Oral Res 2005;19(3):188-92.

solution caused by the increase in the constituent concentration. At high concentrations, citrate monopolises such a large portion of the solvent that the amount of solvent available for $\mathrm{Ca}^{2+}$ diffusion is dramatically reduced.

Furthermore, the self-limiting effect associated with $\mathrm{pH}$ changes during the demineralisation process of EDTA, EGTA and CDTA can be considered. These chelating agents react with calcium ions in the hydroxyapatite crystals to produce a metallic chelate, and this process is characterised by protonation and complex formation reaction occurs $^{9}$. As the $\mathrm{pH}$ decreases during this process, both the rate of dentin demineralisation and the amount of dentin dissolved decrease.

The irrigating solutions used in this experiment were of low concentrations. It should be mentioned that EDTA is currently studied or used in clinical practice with concentrations between $15-17 \%$. In fact, this is the first study comparing EDTA with EGTA, CDTA and citric acid at the same concentration and $\mathrm{pH}$. Comparison between two different $\mathrm{pH}$ values of citric acid and the chelating agents was essential to confirm its action at lower $\mathrm{pH}$ and concentration values. Few studies have evaluated its action using these parameters so far.

Even though EGTA is reported to bind $\mathrm{Ca}^{2+}$ more specifically than EDTA, in some studies, although different analyses and concentrations have been used, EGTA was similar or less potent than EDTA. Calt, Serper ${ }^{1}$ (2000) indicated that the action of $17 \%$ EDTA is stronger than that of $17 \%$ EGTA for removal of smear layer. However, EGTA did not cause erosion of the intertubular and peritubular dentin. Cruz-Filho et al. ${ }^{2}$ (2001) reported that 1\% EGTA, 1\% CDTA and 15\% EDTAC reduced root dentin microhardness similarly. Viswanath et al. $^{16}$ (2003), in a SEM study, demonstrated that both EGTA and EDTA completely removed the smear layer.

There was a molar concentration difference between all test solutions, but this difference was smaller among chelating agents. The present study revealed that EDTA and EGTA presented the same effect on dentin $\mathrm{Ca}^{2+}$ extraction. However, CDTA was statistically less effective, though its molar concentration was slightly higher than that of EDTA and EGTA. Note that the citric acid solution had almost double the molar concentration when compared with the other solutions.
Previous reports have shown that 15\% EDTAC presented similar action when compared with $1 \%$ EGTA and 1\% $\mathrm{CDTA}^{2}$, and that EDTA-T was less effective than $\mathrm{EDTA}^{8}$ as a chelating agent. The present data demonstrated that 1\% EDTA alone was as efficient as 1\% EGTA and better than 1\% CDTA. The concentration and association with other substances can be an important factor on the chelating agents' action process.

Considering the present results on the similar effect of 1\% EDTA and 1\% EGTA for removal of smear layer, the previous literature ${ }^{1,2,16}$, and their cytotoxic effect ${ }^{2,6,7,9-11,16}$, EGTA should be preferred when a chelating agent is required.

All acid solutions tested in this experiment are considered complexants and chelating agents. Under the conditions of this study, $1 \%$ citric acid (pH 1.0) demonstrated to be a good alternative as an irrigating solution to remove the smear layer and facilitate the biomechanical procedures. Scelza et al. ${ }^{8}$ (2003) also suggested the use of citric acid as an irrigating solution despite the lack of statistical difference between citric acid and 17\% EDTA in terms of their efficacy in $\mathrm{Ca}^{2+}$ extraction from root dentin. Citric acid was reported to be inexpensive, effective on anaerobic microorganisms ${ }^{17}$ and more biocompatible than EDTA and EGTA ${ }^{7,9-11}$. Sousa ${ }^{11}$ (2000) and Soares, Sousa ${ }^{10}$ (2003) reported that, even at $15 \%$ and $\mathrm{pH} 1.0$, citric acid was less cytotoxic than 15\% EDTA. The 15\% EGTA solution was more biocompatible than EDTA.

Combinations of decalcifying agents and $\mathrm{NaOCl}$ solution have been recommended, because no single irrigator is capable of dissolving organic pulpal material and predentin as well as demineralising the inorganic calcified portion of the root canal wall. The authors suggested that the acidity yielded by utilisation of chemical solutions on endodontic therapy could be minimised by final flushing with water and use of calcium hydroxide sealers, which could neutralize this residual effect. Besides, the application time should also be well controlled in the etching procedure. Attention to these factors will lower the risk of damage to the dental tissue during root canal cleaning and thus increase the success of endodontic therapy.

\section{CONCLUSION}

According to this in vitro study, the $1 \%$ citric acid at $\mathrm{pH} 1.0$ proved to be the most effective solution for root dentin $\mathrm{Ca}^{2+}$ extraction. Lower concen- 
Sousa SMG, Silva TL. Demineralization effect of EDTA, EGTA, CDTA and citric acid on root dentin: a comparative study. Braz Oral Res 2005;19(3):188-92.

trations of EDTA and EGTA were found to be more effective than CDTA; 1\% EDTA and 1\% EGTA had similar demineralisation effect on dentin. Citric acid at neutral $\mathrm{pH}$ did not significantly change the calcium content of root dentin.

\section{REFERENCES}

1. Çalt S, Serper A. Smear layer removal by EGTA. J Endod 2000;26:459-61.

2. Cruz-Filho AM, Sousa-Neto MD, Saquy PC, Pécora JD. Evaluation of the effect of EDTAC, CDTA, and EGTA on radicular dentin microhardness. J Endod 2001;27:183-4.

3. Ferrer-Luque CMF, González-López SG, Rodrígues de Mondelo JMN. Utilización del ácido cítrico en la preparación biomecánica del conducto radicular. Endodoncia 1994;12:63-70.

4. Haznedaroglu F. Efficacy of various concentrations of citric acid at different $\mathrm{pH}$ values for smear layer removal. Oral Surg Oral Med Oral Pathol Oral Radiol Endod 2003;96:340-4.

5. Hennequin M, Pajot J, Avignant D. Effects of different $\mathrm{pH}$ values of citric acid solutions on the calcium and phosphorus contents of human root dentin. J Endod 1994;20:551-4.

6. McInnes-Ledoux P, Cleaton-Jones PE, Austin JC. The pulpal response to dilute citric acid smear removers. J Oral Rehabil 1985;12:215-28.

7. Scelza MFZ, Daniel RLDP, Santos EM, Jaeger MMM. Cytotoxic effects of $10 \%$ citric acid and EDTA-T used as root canal irrigants: an in vitro analysis. J Endod 2001;27:741-3.

8. Scelza MFZ, Teixeira AM, Scelza P. Decalcifying effect of EDTA-T, $10 \%$ citric acid, and 17\% EDTA on root canal dentin. Oral Surg Oral Med Oral Pathol Oral Radiol Endod 2003;95:234-6.

9. Segura-Egea JJ, Jimenez-Rubio A, Rios-Santos JV, Velasco-Ortega $\mathrm{E}$, Calvo-Gutierrez JR. In vitro inhibitory effect of EGTA on macrophage adhesion: endodontic implications. J Endod 2003;29:211-3.

10. Soares AB, Sousa SMG. Avaliação da biocompatibilidade do EDTA, EGTA e ácido cítrico em tecido subcutâneo de ratos. Rev Odonto Ciência 2003;18:17-22.

11. Sousa SMG. Avaliação da biocompatibilidade do EDTA, EGTA e ácido cítrico pela técnica de exsudação de corantes vitais [Tese de Doutorado]. Bauru: Faculdade de Odontologia de Bauru da USP; 2000.

12. Sousa-Neto MD, Passarinho-Neto JG, Carvalho-Júnior JR, Cruz-Filho AM, Pécora JD, Saquy PC. Evaluation of the effect of EDTA, EGTA and CDTA on dentin adhesiveness and microleakage with different root canal sealers. Braz Dent J 2002;13:123-8.

13. Sterrett JD, Bankey T, Murphy HJ. Dentin demineralization. The effects of citric acid concentration and application time. J Clin Periodontol 1993;20:366-70.

14. Sterrett JD, Delaney B, Rizkalla A, Hawkins CH. Optimal citric acid concentration for dentinal demineralization. Quintessence Int 1991;22:371-5.

15. Trujillo Júnior R, Silva FB, Almeida JM, Sousa SMG. Avaliação da biocompatibilidade do ácido cítrico em diferentes concentrações - teste edemogênico. Salusvita 2003;22:171-80.

16. Viswanath D, Hegde AM, Munshi AK. The removal of the smear layer using EGTA: a scanning electron microscopic study. J Clin Pediatr Dent 2003;28:69-74.

17. Yamaguchi M, Yoshida K, Suzuki R, Nakamura H. Root canal irrigation with citric acid solution. J Endod 1996;22:27-9.

Received for publication on Sep 17, 2004

Sent for alterations on Oct 25, 2004

Accepted for publication on May 27, 2005 